\title{
Estimation of atmospheric particle formation rates through an analytical formula: validation and application in Hyytiälä and Puijo, Finland
}

\author{
Elham Baranizadeh $^{1}$, Tuomo Nieminen ${ }^{1}$, Taina Yli-Juuti ${ }^{1}$, Markku Kulmala $^{2}$, Tuukka Petäjä ${ }^{2}$, Ari Leskinen ${ }^{1,3}$, \\ Mika Komppula $^{3}$, Ari Laaksonen ${ }^{1,4}$, and Kari E. J. Lehtinen ${ }^{1,3}$ \\ ${ }^{1}$ Department of Applied Physics, University of Eastern Finland, Kuopio, Finland \\ ${ }^{2}$ Department of Physics, University of Helsinki, Helsinki, Finland \\ ${ }^{3}$ Finnish Meteorological Institute, Kuopio, Finland \\ ${ }^{4}$ Climate research Unit, Finnish Meteorological Institute, Helsinki, Finland
}

Correspondence to: Kari E. J. Lehtinen (kari.lehtinen@uef.fi)

Received: 11 October 2016 - Discussion started: 9 January 2017

Revised: 31 August 2017 - Accepted: 9 September 2017 - Published: 10 November 2017

\begin{abstract}
The formation rates of $3 \mathrm{~nm}$ particles were estimated at SMEAR IV, Puijo (Finland), where the continuous measurements extend only down to $7 \mathrm{~nm}$ in diameter. We extrapolated the formation rates at $7 \mathrm{~nm}\left(J_{7}\right)$ down to $3 \mathrm{~nm}\left(J_{3}\right)$ based on an approximate solution to the aerosol general dynamic equation, assuming a constant condensational growth rate, a power-law size-dependent scavenging rate, and negligible self-coagulation rate for the nucleation mode particles. To evaluate our method, we first applied it to new particle formation (NPF) events in Hyytiälä (Finland), which extend down to $3 \mathrm{~nm}$, and, therefore, $J_{3}$ and $J_{7}$ can be determined directly from the measured size distribution evolution. The Hyytiälä results show that the estimated daily mean $J_{3}$ values slightly overestimate the observed mean $J_{3}$, but a promising $91 \%$ of the estimated $J_{3}$ values are within a factor of 2 from the measured ones. However, when considering detailed daily time evolution, the agreement is not as good due to fluctuations in data as well as uncertainties in estimated growth rates, which are required in order to calculate the time lag between formation of 3 and $7 \mathrm{~nm}$ particles. At Puijo, the mean $J_{7}$ for clear NPF days during April 2007-December 2015 was $0.44 \mathrm{~cm}^{-3} \mathrm{~s}^{-1}$, while the extrapolated mean $J_{3}$ was $0.61 \mathrm{~cm}^{-3} \mathrm{~s}^{-1}$.
\end{abstract}

\section{Introduction}

Atmospheric new particle formation (NPF) events, i.e., nucleation and subsequent growth of newly formed particles, have received increasing attention due to their impact on climate and human health (Kulmala et al., 2004; Merikanto et al., 2009; Nie et al., 2014; Kerminen et al., 2012; Fuzzi et al., 2015; Minguillón et al., 2015, and references therein). Many studies have been conducted to find out which variables cause and which possibly inhibit NPF events. Sulfuric acid, water, and ammonia have already long been considered important molecules for atmospheric new particle formation (Weber et al., 1995, 1996; Korhonen et al., 1999; Kulmala et al., 2000; Laaksonen et al., 2008; Xiao et al., 2015). More recently, studies show that amines, ions, and volatile organic vapors can play an important role in NPF events either by participating in the nucleation itself or by stabilizing the nucleated clusters (e.g., Almeida et al., 2013; Berndt et al., 2014; Bianchi et al., 2016; Kirkby et al., 2016). However, several features of atmospheric nucleation, including the actual mechanism in different environments and other possible vapors involved (Kulmala et al., 2006; Lehtinen et al., 2007), remain unknown.

The lack of exact knowledge of atmospheric NPF mechanisms is partly because, at several locations, particle size distribution measurements do not extend to nucleation size range but instead start at ca. $3 \mathrm{~nm}$ or even at larger sizes (e.g., 7 or $10 \mathrm{~nm}$ ). This limits the use of the particle data 
in NPF studies and poses a challenge in understanding NPF globally. In addition, the actual nucleation rates of sub- $2 \mathrm{~nm}$ particles remain unknown. Even with data obtained by the new condensation particle counters (CPCs), which have cutoff mobility diameters of sub-2 nm (Sgro and Fernández de la Mora, 2004; Iida et al., 2009; Vanhanen et al., 2011; Kuang et al., 2012; Wimmer et al., 2013), the determination of nucleation rates still involves approximation, for example, due to composition-dependent detection efficiencies and high loss rates of the smallest particles.

Measuring sub-3 nm particles is a challenging task because of their diffusion loss during transporting the sample, difficulties in collecting representative samples for electrical detection, difficulties in charging them for electrical size selection (classification), their insufficient amount to be chemically analyzed, and the need for a very high supersaturation condition to grow them to large enough sizes that they can be optically detected (Kulmala et al., 2012). Because of these challenges in measuring small particles, methods to extrapolate size distributions and formation rates below the measurement range have been suggested by McMurry and Friedlander (1979), McMurry and Wilson (1982), McMurry (1983), Weber et al. (1996), Kerminen and Kulmala (2002), Kerminen et al. (2003), Lehtinen et al. (2007), and most recently by Kürten et al. (2015). We are, however, not aware of another study in which these methods have been tested with atmospheric measurement data.

Our study has two main goals. Firstly, we aim to estimate $3 \mathrm{~nm}$ particle formation rates $J_{3}$ for Puijo, where continuous size distribution measurements have been going on since 2006 . We estimate the $J_{3}$ by a scaling method based on aerosol dynamics theory for the range $3-7 \mathrm{~nm}$ because the measured size range at Puijo has been only down to $7 \mathrm{~nm}$ in diameter. Therefore, our second main goal is to validate our method to estimate $J_{3}$. For this, we use size distributions measured at Hyytiälä, where detailed particle size distribution measurements down to $3 \mathrm{~nm}$ have been performed since 1996. From the Hyytiälä data we can thus evaluate formation rates both at 3 and $7 \mathrm{~nm}$. The fraction of particles that survives the scavenging by larger aerosols is determined by the ratio of their growth and scavenging rates (Kerminen et al., 2004). In this study, we use the method of Lehtinen et al. (2007) in which time- and size-independent particle growth rate as well as time-independent but size-dependent coagulation sink are assumed.

\section{Methods}

\subsection{Data sets and site descriptions}

In this study we use the aerosol size distribution measurements at two different SMEAR (Station for Measuring Ecosystem-Atmosphere Relations) stations in Finland: SMEAR II located in Hyytiälä and SMEAR IV in Kuopio.
The data from the SMEAR stations are publicly available through Smart-SMEAR; for more details see Junninen et al. (2009).

SMEAR II (Hyytiälä, southern Finland; 61 $51^{\prime} \mathrm{N}$, $24^{\circ} 17^{\prime} \mathrm{E}$; $181 \mathrm{~m}$ a.s.1.) is characterized by boreal coniferous forest. The main pollution sources are the city of Tampere (60 km away) and the buildings at the station. These sources are most effective when the wind is from the southwest direction (Kulmala et al., 2001). For this study we analyzed aerosol size distributions measured at SMEAR II with a differential mobility particle sizer (DMPS; Aalto et al., 2001), with a cut-off size at $3 \mathrm{~nm}$, between years 2000 and 2012 .

At SMEAR IV the instruments are set up at the top of the Puijo observation tower $\left(62^{\circ} 54^{\prime} 34^{\prime \prime} \mathrm{N}, 27^{\circ} 39^{\prime} 19^{\prime \prime} \mathrm{E}\right), 306$ and $224 \mathrm{~m}$ a.s.l. and the surrounding lake level, respectively). Puijo tower is located in the city of Kuopio (eastern Finland), a semi-urban environment with surroundings characterized by forest with conifer and deciduous (mostly birch) trees, and many lakes. The main local sources surrounding the tower are a paper mill (in the direction $35^{\circ}$ from the station, distance $>1.4 \mathrm{~km}$ ), the city center (direction $120-155^{\circ}$, distance $1.6-3.2 \mathrm{~km}$ ), a heating plant (direction $160^{\circ}$, distance $3.5 \mathrm{~km}$ ), a highway, and residential areas (see Leskinen et al., 2009, and Portin et al., 2014, for more details). The aerosol size distribution is measured with a twin DMPS (Winklmayr et al., 1991; Jokinen and Mäkelä, 1997) covering the size range $7-800 \mathrm{~nm}$ (Leskinen et al., 2009). The twin DMPS consists of two differential mobility analyzer (DMA) tubes, one shorter with $11 \mathrm{~cm}$ length and another one longer with $28 \mathrm{~cm}$ length, and a condensation particle counter (TSI Model 3010 CPC) after each DMA tube. In both DMPS systems, the sample is neutralized (before it enters to the DMA) into charge equilibrium by a beta radiation source (Ni-63 $10 \mathrm{mCi}=370 \mathrm{MBq}$ ). The size range measured by the longer tube is $27-800 \mathrm{~nm}$ with 29 discrete bins and 7-49 nm with 17 discrete bins for the shorter tube. The full particle size distribution $(7-800 \mathrm{~nm}$ ) is measured every $12 \mathrm{~min}$ (Leskinen et al., 2009). At Puijo there is a twin-inlet system for aerosolcloud interaction studies: one inlet removes cloud droplets (when the station is in a cloud) and collects only the interstitial particles, and the other inlet collects the total aerosol (i.e., cloud droplets and interstitial particles). When the station is not in a cloud, the size distributions measured from both inlets are the same. In this study, we used the data from the total aerosol inlet and analyzed aerosol size distributions measured between April 2007 and December 2015.

\subsection{Data analysis method}

Kerminen and Kulmala (2002) derived an analytical formula which links the "real" particle formation rate and the "apparent" formation rates of particles of larger sizes for which measurements are available (typically above $3 \mathrm{~nm}$ ). The formula was later improved by Lehtinen et al. (2007) by (1) correcting the slightly inaccurate size dependence of the coagu- 
lation sink and (2) removing the unnecessary assumption of the identity of the condensing vapor. According to the formula (Eq. 7 in Lehtinen et al., 2007), one can estimate the formation rate of smaller particles $\left(J_{d 1}\right)$ with diameter $d_{1}$, for which no measurements are available, from the formation rate of measured larger particles $\left(J_{d 2}\right)$ with diameter $d_{2}$, as follows:

$J_{d_{1}}=J_{d_{2}} \cdot \exp \left(\gamma \cdot d_{1} \cdot \frac{\operatorname{CoagS}\left(d_{1}\right)}{\mathrm{GR}}\right)$

with $\quad \gamma=\frac{1}{m+1}\left(\left(\frac{d_{2}}{d_{1}}\right)^{m+1}-1\right) \quad$ and $\quad m=$ $\frac{\log \left[\operatorname{CoagS}\left(d_{2}\right) / \operatorname{CoagS}\left(d_{1}\right)\right]}{\log \left[d_{2} / d_{1}\right]}$, where CoagS is the coagulation sink of smaller particles (diameter $d_{1}$ ) onto the background particles, and GR is the particle growth rate (which is assumed to be constant from diameter $d_{1}$ to diameter $d_{2}$ ).

In this study, we apply the Eq. (1) to estimate the apparent formation rates of particles of $3 \mathrm{~nm}$ in diameter at Puijo, where the size distribution of particles below $7 \mathrm{~nm}$ is not measured. To derive Eq. (1) (i.e., Eq. 7 in Lehtinen et al., 2007), it was assumed that the growth rate between $d_{1}$ and $d_{2}$ is constant. This assumption, however, can fail especially for sizes below $3 \mathrm{~nm}$, where some recent studies have indicated strong size dependence of GR (Kuang et al., 2012; Kulmala et al., 2013).

Korhonen et al. (2014) modified Eq. (1) to also include either linear or power-law type size-dependent growth rate and tested the method by using modeled NPF events. In their studies especially the method assuming power-law type growth rate gave promising results with various types of sizedependent growth profiles. However, in this study, we assume a constant GR because, as mentioned earlier, a strong size dependency of GR has been reported for very small particles typically below $3 \mathrm{~nm}$ (e.g., Kuang et al., 2012) rather than for larger sizes. The other assumption when deriving Eq. (1) is that the nucleating particles are lost only by coagulation onto larger preexisting particles. Lehtinen et al. (2003) studied the contribution of particles of different sizes to the condensation sink at Hyytiälä and found that particles below $50 \mathrm{~nm}$ in diameter have typically negligible contribution. This is a reasonable assumption at Puijo also as the concentrations and size distributions are similar to those at Hyytiälä. The mean values of CoagS of $7 \mathrm{~nm}$ particles are $5.41 \times 10^{-5}$ and $5.29 \times 10^{-5} \mathrm{~s}^{-1}$ in Hyytiälä (event days during 2002-2012) and Puijo (event days during 2007-2015), respectively.

To evaluate Eq. (1) against measurements, we use the particle size distribution evolution data during nucleation event days from SMEAR II. There the measurements have extended down to $3 \mathrm{~nm}$ in diameter; therefore, one is able to get apparent formation rates at $7 \mathrm{~nm}\left(J_{7}\right)$ and at $3 \mathrm{~nm}$ $\left(J_{3}\right)$ directly from measurements. We then set $d_{1}=3 \mathrm{~nm}$ and $d_{2}=7 \mathrm{~nm}$ in Eq. (1) and calculate $J_{3, \text { obs }}$ and $J_{7, \text { obs }}$ as outlined in Kulmala et al. (2012) and slightly improved in Vuollekoski et al. (2012). Here we use the subscript obs to indicate observed apparent formation rates $J$. The formation rates of particles of $3 \mathrm{~nm}\left(J_{3, \text { obs }}\right)$ and $7 \mathrm{~nm}\left(J_{7, \mathrm{obs}}\right)$ in diameter from measured aerosol size distribution were calculated as follows:

$J_{3, \text { obs }}=\frac{\mathrm{d} N_{3-7}}{\mathrm{~d} t}+n_{7} \cdot \mathrm{GR}_{7-20},+N_{3-7} \operatorname{CoagS}\left(d_{\mathrm{GMD}}\right)$,

where $n_{7}=\frac{N_{5-9}}{9-5}$ and $d_{\mathrm{GMD}}=\sqrt{3 \times 7} \mathrm{~nm}$.

$J_{7, \mathrm{obs}}=\frac{\mathrm{d} N_{7-10}}{\mathrm{~d} t}+n_{10} \cdot \mathrm{GR}_{7-20}+N_{7-10} \cdot \operatorname{CoagS}\left(d_{\mathrm{GMD}}\right)$,

where $n_{10}=\frac{N_{8-12}}{12-8}$ and $d_{\mathrm{GMD}}=\sqrt{7 \times 10} \mathrm{~nm}$.

Here $N_{3-7}, N_{5-9}, N_{7-10}$, and $N_{8-12}$ are the number concentration of particles within size ranges 3-7, 5-9 nm, 7-10, and $8-12 \mathrm{~nm}$, respectively, and $n_{7}$ and $n_{10}$ are the size distribution function at 3 and $7 \mathrm{~nm}$, respectively. The coagulation sink (CoagS) terms were calculated directly from the measured particle size distributions, taking into account the hygroscopicity effects using the parameterization of Laakso et al. (2004), who used the hygroscopic growth factor parameterization by Zhou (2001). We used a parabolic differentiation method on the measured number concentration to obtain its time derivative (the first term in Eqs. 2 and 3). The method fits a second-order polynomial to seven data points centered at the data point where derivative is calculated while at the edges a parabola is fit through the first or last six data points, from which the derivative is calculated directly. Also, to avoid spurious fluctuations in the second and third terms in Eqs. (2) and (3), the $N_{3-7}, N_{5-9}, N_{7-10}$, and $N_{8-12}$ were smoothed using a moving-average (over five data points) filter.

The estimated formation rate $J_{3}$ was then calculated based on Eq. (1):

$J_{3, \text { est }}(t)=J_{7, \text { obs }}\left(t^{\prime}\right) \cdot \exp \left(\gamma(t) \cdot 3 \mathrm{~nm} \cdot \frac{\operatorname{CoagS}\left(d_{1}=3 \mathrm{~nm}\right)}{\mathrm{GR}_{3-10}}\right)$.

Note $J_{3, \text { est }}$ at time $t$ is calculated based on $J_{7, \mathrm{obs}}$ at time $t^{\prime}$, where $t=t^{\prime}-\frac{4 \mathrm{~nm}}{\mathrm{GR}_{3-10}}$, thus accounting for the growth time of the $3 \mathrm{~nm}$ particles to $7 \mathrm{~nm}$ particles. To average over this time interval needed for growth, the $m$ and $\operatorname{CoagS}\left(d_{1}\right)$ values are calculated as medians of the corresponding values during time $t$ to $t^{\prime}$.

To determine the growth rates required in this study, we used the maximum-concentration method (Lehtinen et al., 2003; Yli-Juuti et al., 2011). In this method, the particle growth rates are determined from the times of the concentration maxima in each of the size bins of the measured particle number size distributions. A linear function is fitted to the data points of the geometric mean diameters of the size bins as function of the determined times of the concentration maxima in the size bins, and the growth rate GR is the slope of this linear function. We also tested another GR determination method, which uses log-normal mode-fitting of the 

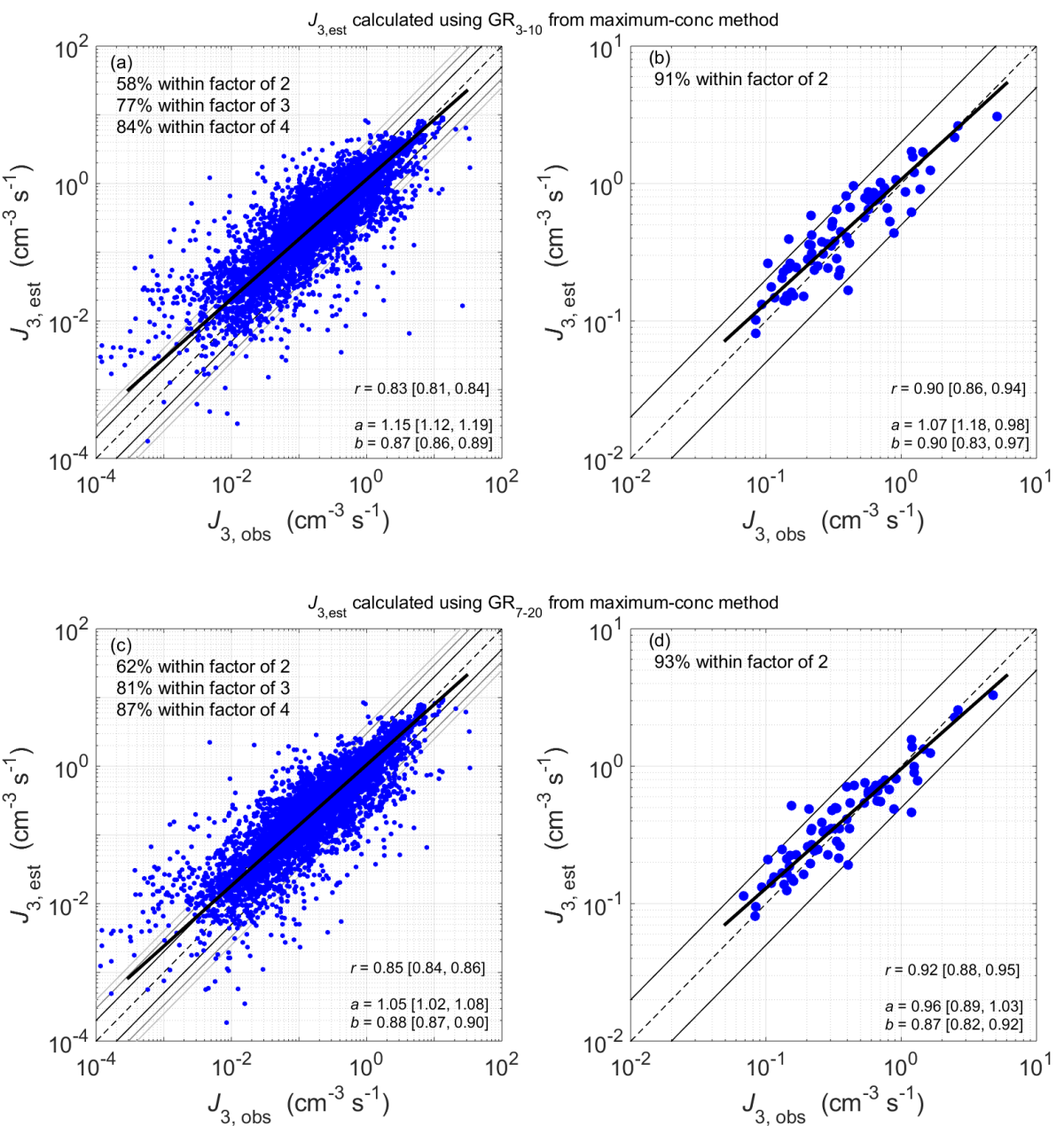

Figure 1. Comparison of the estimated $\left(J_{3, \text { est }}\right)$ against observed $\left(J_{3, \text { obs }}\right)$ formation rates of $3 \mathrm{~nm}$ particles during the selected new particle

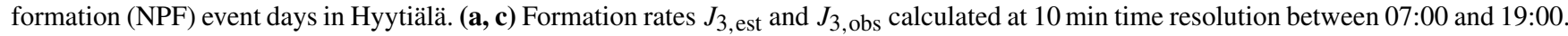
Note that the time lag during which particles grow from 3 to $7 \mathrm{~nm}$ is taken into account in the $J_{3 \text {, est }}$ (b, d) Arithmetic mean of formation rates between 07:00 and 19:00 local time for each NPF day. Panels in the top row refer to $J_{3 \text {, est }}$ results calculated using GR $3-10$ and the bottom row to those calculated using $\mathrm{GR}_{7-20}$. The black lines show the bivariate linear fits to the logarithmic data values; the corresponding parameter values of the fit equations $J_{3 \text {, est }}=a \cdot J_{3 \text {,obs }}^{b}$ and the correlation coefficients $r$ are given in each panel. The values in square brackets show the 5th and 95th percentile bootstrap confidence intervals of the parameter values. The fractions of $J_{3 \text {, est }}$ that are within factor of 2 of $J_{3, \text { obs }}$ are shown in the upper left corner of each subplot (for the $10 \mathrm{~min}$ time resolution data also data points within fraction of 3 and 4 are shown).

Table 1. Overall and seasonal mean values of the observed formation rates of $7 \mathrm{~nm}$ particles $\left(J_{7, \text { obs }}\right)$, the estimated formation rates of $3 \mathrm{~nm}$ particles $\left(J_{3, \text { est }}\right)$, the growth rates of particles in size range $7-20 \mathrm{~nm}\left(\mathrm{GR}_{7-20}\right)$, and the coagulation sink of 7 nm particles onto larger particles $\left(\mathrm{CoagS}_{7}\right)$ for $105 \mathrm{NPF}$ days which occurred at Puijo during April 2007-December 2015. The $J_{7 \text {,obs }}, J_{3 \text {, est }}$, and CoagS 7 include data during 07:00-19:00 on each NPF day.

\begin{tabular}{lcccc}
\hline & $\begin{array}{c}J_{7, \text { obs }} \\
\left(\mathrm{cm}^{-3} \mathrm{~s}^{-1}\right)\end{array}$ & $\begin{array}{c}J_{3, \text { est }} \\
\left(\mathrm{cm}^{-3} \mathrm{~s}^{-1}\right)\end{array}$ & $\begin{array}{c}\mathrm{GR}_{7-20} \\
\left(\mathrm{~nm} \mathrm{~h}^{-1}\right)\end{array}$ & $\begin{array}{c}\mathrm{CoagS}_{7} \\
\left(\mathrm{~s}^{-1}\right)\end{array}$ \\
\hline Winter (Dec-Feb) & 0.16 & 0.22 & 4.3 & $1.4 \times 10^{-4}$ \\
Spring (Mar-May) & 0.49 & 0.70 & 5.0 & $1.9 \times 10^{-4}$ \\
Summer (Jun-Aug) & 0.85 & 1.12 & 8.0 & $2.3 \times 10^{-4}$ \\
Fall (Sep-Nov) & 0.27 & 0.40 & 5.7 & $1.7 \times 10^{-4}$ \\
Overall & 0.44 & 0.61 & 5.8 & $1.8 \times 10^{-4}$ \\
\hline
\end{tabular}



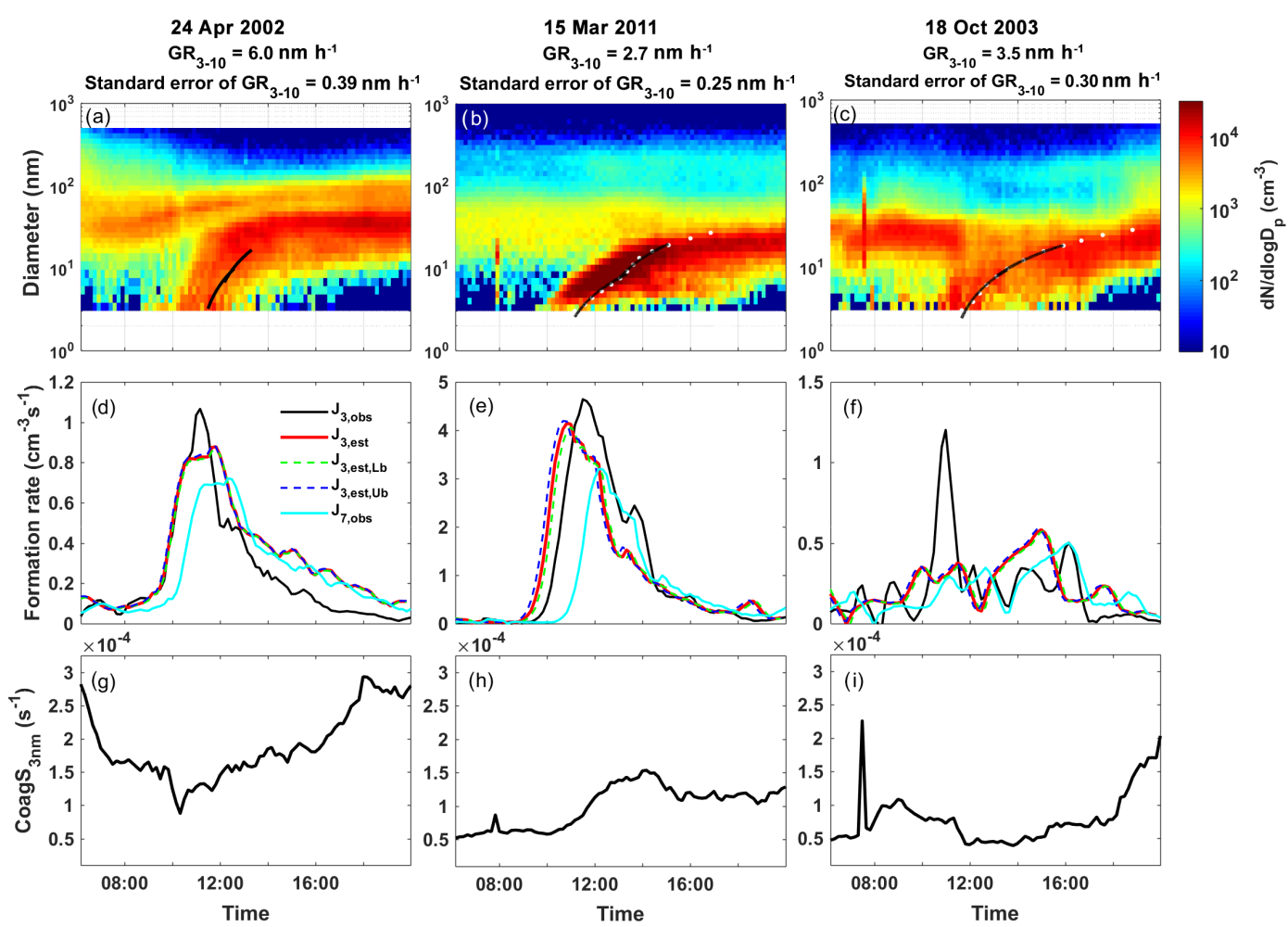

Figure 2. Examples of Hyytiälä NPF events. $(\mathbf{a}, \mathbf{b}, \mathbf{c})$ the evolution of the particle number size distribution. White dots represent the times of the maximum concentration in each size bin of the measured size distribution, and the solid black line shows the first-order polynomial fit to those data points. (d, e, f) The corresponding time evolution of $3 \mathrm{~nm}$ particle formation rates $J_{3 \text {,obs }}$ obtained from Eq. (2) (black line), observed formation rates of $7 \mathrm{~nm}$ particles $J_{7 \text {,obs }}$ obtained from Eq. (3) (cyan line), and the estimated formation rate of $3 \mathrm{~nm}$ particles $J_{3 \text {, est }}$ calculated by Eq. (4) (red line). The dashed lines show the upper bound ( $\left.J_{3, \text { est, Ub }}\right)$ and lower bound ( $J_{3, \text { est,Lb }}$ calculated by Eq. (4) using the lower $\left(\mathrm{GR}_{3-10}-\mathrm{SE}\right)$ and upper $\left(\mathrm{GR}_{3-10}+\mathrm{SE}\right)$ bound of $\mathrm{GR}_{3-10}$, respectively. $(\mathbf{g}, \mathbf{h}, \mathbf{i})$ The time evolution of the coagulation sink of $3 \mathrm{~nm}$ particles.
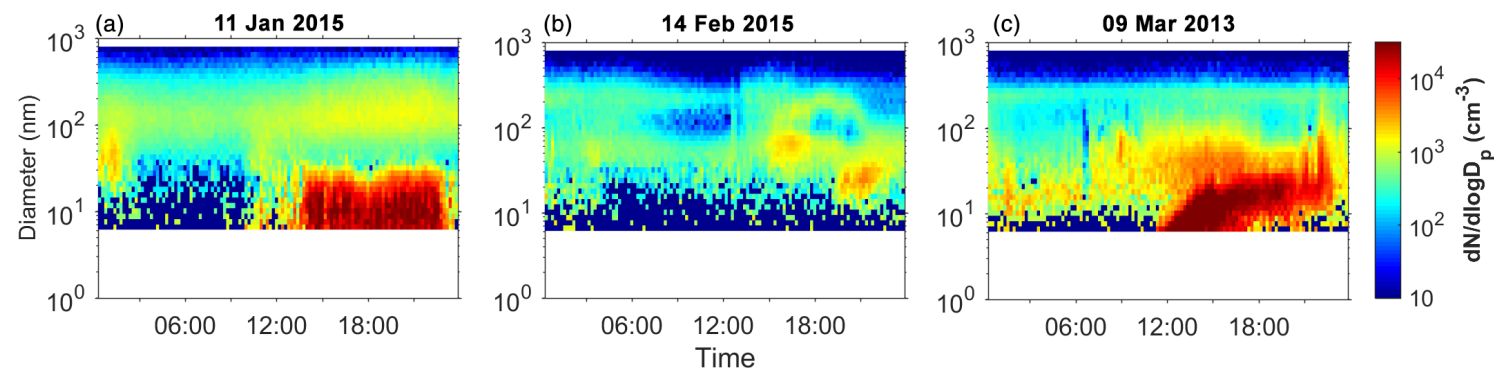

Figure 3. Examples of the time evolution of the aerosol size distribution in Puijo for (a) an undefined day characterized by a burst in the number concentrations of the small particles which does not have the characteristics of a typical NPF event day, (b) a typical undefined day, and (c) a clear NPF event day.

measured size distributions to follow the growth of the particles (Yli-Juuti et al., 2011). However, when comparing in Hyytiälä the observed $3 \mathrm{~nm}$ particle formation rates to those estimated using GR from both maximum-concentration and mode-fitting methods, it become apparent that the maximumconcentration method yielded better results. Therefore, we chose to use the GR from maximum-concentration method in Eqs. (2)-(4). We left out the days where the growth rates required in the aforementioned equations (i.e., $\mathrm{GR}_{3-10}$ and/or $\mathrm{GR}_{7-20}$ ) were not quantifiable. We chose the size range 3$10 \mathrm{~nm}$ rather than $3-7 \mathrm{~nm}$ to determine the GR in the exponential term of Eq. (4) (denoted as $\mathrm{GR}_{3-10}$ ). This was done to increase the number of data points in the GR fitting and thereby to improve the reliability of the fitted GR.

After evaluating the analysis method with SMEAR II data, we applied the method for Puijo, where the DMPS detection 

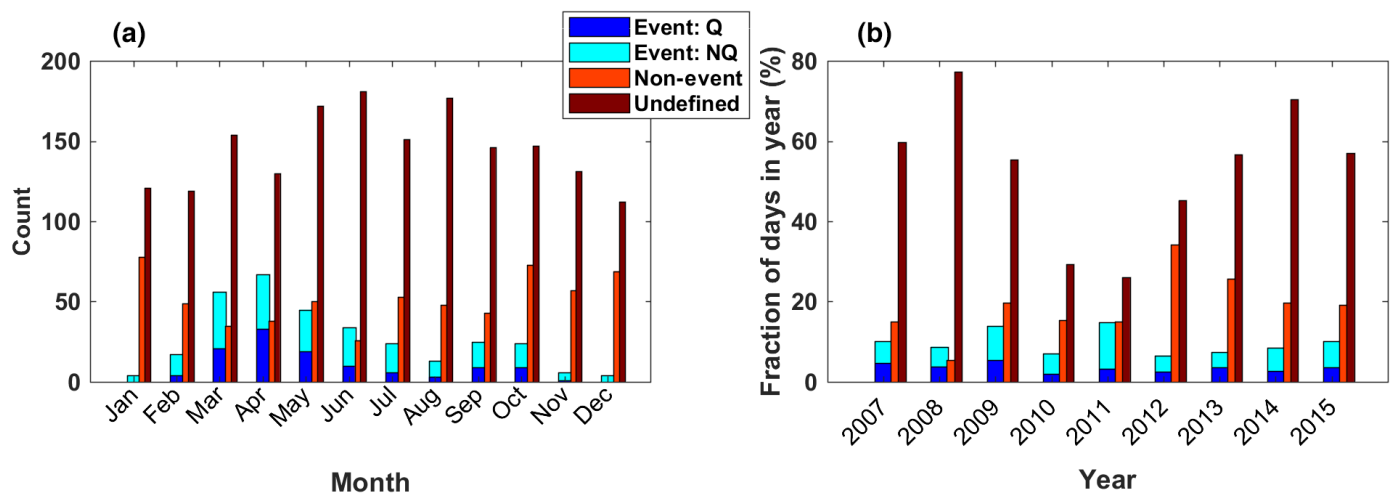

Figure 4. Monthly number (a) and yearly fraction (b) of NPF event days (divided into quantifiable events (Q) and non-quantifiable events (NQ)), non-events (NEs), and undefined days recorded in Puijo during period 2007-2015. Fraction of (e.g., NE) days in year is the ratio of number of NEs and number of days within the year. Note that the days for which bad or no data were recorded are not shown here. Note that 48 and $44 \%$ of the days are missing during years 2010 and 2012, respectively.

range extended only down to $7 \mathrm{~nm}$. To estimate the formation rate of $3 \mathrm{~nm}$ particles at Puijo we adapted Eq. (4) by replacing $\mathrm{GR}_{3-10}$ with $\mathrm{GR}_{7-20}$ due to lack of DMPS measurements below $7 \mathrm{~nm}$. However, as it will be shown in Sect. 3.1, using $\mathrm{GR}_{7-20}$ instead of $\mathrm{GR}_{3-10}$ does not affect the accuracy of estimated $J_{3}$ for NPF events in Hyytiälä, which is an indication that the size dependence of the growth rate in the range 3-20 nm is typically weak. The $J_{7 \text {,obs }}$ was calculated with the same method as was used for Hyytiälä (i.e., using Eq. 3).

\section{Results and discussion}

\subsection{Analysis of estimated $J_{3}$ in Hyytiälä (Finland)}

Figure 1 shows the comparison of estimated formation rates $J_{3, \text { est }}$ (Eq. 4) with the observed ones $J_{3, \text { obs }}$, as calculated directly from the measured size distribution evolution according to Eq. (2) in Hyytiälä. In the top figures, the range 3$10 \mathrm{~nm}$ is used to evaluate the growth rate, in the bottom ones $7-20 \mathrm{~nm}$. We analyzed $65 \mathrm{NPF}$ event days for which the formation and growth rates could be quantified. Each data point in Fig. $1 \mathrm{~b}$ and $\mathrm{d}$ represents the arithmetic mean of the $3 \mathrm{~nm}$ particle formation rates $\left(J_{3, \text { est }}\right.$ and $\left.J_{3, \text { obs }}\right)$ for a single NPF day during the time window from 07:00 to 19:00 local time. The mean is also a measure of the total particle production strength of each event. The results show that, when using GR in the range $3-10 \mathrm{~nm}$, the estimated mean $J_{3, \text { est }}$ values correlate with $J_{3, \text { obs }}$ with a correlation coefficient of 0.90 and a slope of 0.90 using bilinear fitting. Furthermore, $91 \%$ of estimated $J_{3 \text {,est }}$ are within a factor of 2 of the observed $J_{3, \text { obs. }}$. The corresponding numbers when using GR in the range $7-20 \mathrm{~nm}$ are $0.92,0.87$, and $93 \%$. Equation (4) seems to have a tendency of slightly overestimating the formation rate of $3 \mathrm{~nm}$ particles. There is not much difference in the results with different GR size ranges. The total means of $J_{3 \text {,obs }}$ and $J_{3 \text {,est }}$ (not shown in the figure) calculated using $\mathrm{GR}_{3-10}$ are 0.57 and $0.61 \mathrm{~cm}^{-3} \mathrm{~s}^{-1}$, respectively, confirming the tendency of Eq. (4) in slightly overestimating the $3 \mathrm{~nm}$ particle formation rates.

One interesting and important result is that there is not much difference in the estimated formation rates with different GR size ranges. This is both an indication of the weak size independence of GR as well as an encouragement for using GR for the size interval 7-20 nm for Puijo to extrapolate $J$ below $7 \mathrm{~nm}$. The correlation coefficient and the fraction of points within a factor of 2 for the mean formation rates even increase (from 0.90 to 0.92 and from 91 to $93 \%$, respectively) - however, the regression slope decreases from 0.90 to 0.87 .

Figure 1a and c show $J_{3 \text {,obs }}$ versus $J_{3 \text {,est }}$ values with the same $10 \mathrm{~min}$ temporal resolution as for the measured size distribution. The points are within the time window from 07:00 to 19:00 local time. With this higher temporal resolution $J_{3, \text { obs }}$ and $J_{3, \text { est }}$ are clearly correlated (with correlation coefficients of 0.83 and 0.85 for the $\mathrm{GR}_{3-10}$ and $\mathrm{GR}_{7-20}$ cases, respectively), but the match is not as good as for their daily mean values presented in Fig. 1b. For the time-resolved data, $58 \%$ ( $60 \%$ for the $\mathrm{GR}_{7-20}$ case) of the estimated $J_{3 \text {,est }}$ values are within a factor of 2 of the observed $J_{3 \text {,obs. There }}$ are three key reasons for this: (1) there are significant fluctuations in time-resolved experimental size distribution data, (2) the extrapolation method assumes a constant value for CoagS / GR, and (3) there is a time lag between $J_{3}$ and $J_{7}$ and a poor estimation of the growth rate GR results in comparing values at different times. The variation of CoagS with time also affects $m$ and $\gamma$ in Eq. (1). This is, however, negligible as CoagS $(7 \mathrm{~nm}) / \mathrm{CoagS}(3 \mathrm{~nm})$ is a very weak function of time.

Figure 2 shows examples of the time evolution of the particle size distribution, the different formation rates $J$, and Co$\operatorname{agS}(3 \mathrm{~nm})$ on three NPF days in Hyytiälä. For most of the NPF days ( $81 \%$ of the days) the estimated time dependence 

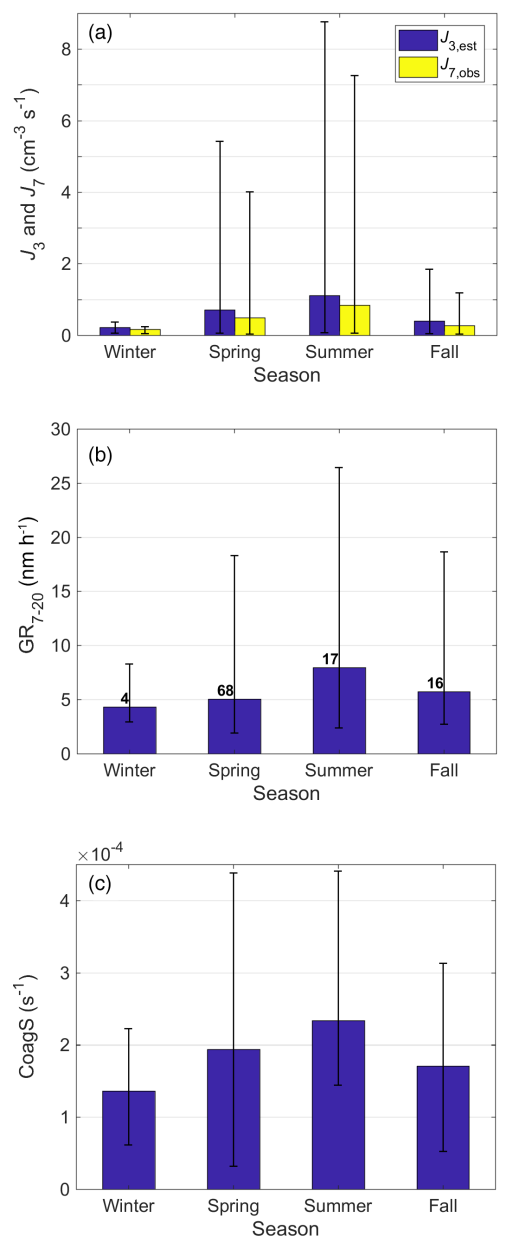

Figure 5. Seasonal mean values of different parameters for NPF days at Puijo: (a) estimated formation rates of $3 \mathrm{~nm}$ particles $\left(J_{3 \text {, est }}\right)$ and observed formation rates of $7 \mathrm{~nm}$ particles $\left(J_{7, \mathrm{obs}}\right)$. (b) Growth rate of the particles within size range 7-20 nm. (c) Coagulation sink (CoagS) of $7 \mathrm{~nm}$ particles. The height of the bars shows the mean values of data points (i.e., mean values during 07:00 to 19:00 of the $J$ and CoagS values for 105 NPF event days) within each season, and the error bars indicate the values between minimum and maximum of the data points. The numbers on top of each bar in middle panel indicate the number of the NPF events in corresponding season. The same applies to Fig. $5 \mathrm{a}$ and c.

of $J_{3 \text {,est }}$ (or time lag between 3 and $7 \mathrm{~nm}$ particle formation rates) is within $1 \mathrm{~h}$ of the observed $J_{3 \text {,obs }}$, and the values of

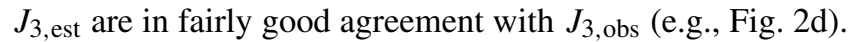
However, the time dependency of $J_{3 \text {,est }}$ is not consistent with $J_{3, \text { obs }}$ for some of the days ( $19 \%$ of the days have larger than $1 \mathrm{~h}$ time difference between $J_{3 \text {,est }}$ and $J_{3 \text {,obs }}$ ) and, instead, typically the $J_{3 \text {,est }}$ peak occurs earlier than the $J_{3 \text {, obs peak }}$ (e.g., Fig. 2e). This indicates that our method of estimating GR is not always perfect and underestimates the GR values. Figure $2 \mathrm{f}$ shows an example of a NPF day for which the $J_{3 \text {,est }}$ and $J_{3 \text {,obs }}$ are dramatically different. This is due to the burst in the number concentration which appeared mostly within the size range $3-7 \mathrm{~nm}$ (chosen to calculate $J_{3 \text {,obs }}$ ) and is thus not included in the size range $7-10 \mathrm{~nm}$ from which $J_{7 \text {,obs }}$ is

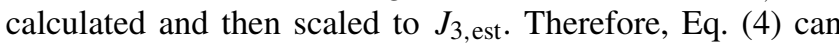
give quite inaccurate results for NPF days associated with, for example, this type of inhomogeneity in the particle number concentrations in different size ranges. This is one of the general problems when analyzing events measured at one fixed location. We do not observe the same aerosol growing, but particles formed at various location appear at the measurement site at various stages of their growth. If we have a large enough homogeneous region of similar formation and growth, there is no problem. However, if there are inhomogeneities and the air mass transport direction changes during an event, we see dynamics as in Fig. 2c and f. It can be also concluded that visual inspection of the data is still valuable cases like this are very challenging for automatic data analysis routines.

\subsection{Estimation of $J_{3}$ in Puijo (Finland)}

For the aerosol size distribution data in Puijo, the NPF event days were first recognized visually and classified as "quantifiable" and "non-quantifiable" based on whether or not the event is homogeneous enough to allow quantification of the basic characteristics such as formation and growth rates (Dal Maso et al., 2005). Therefore, our data pool consists of event (E), non-event (NE), and undefined days, the last being days during which the evolution of the size distribution is too unclear for definitive determination of whether or not NPF has been occurring. Figure 3 shows typical examples of the size distribution dynamics on undefined and NPF days in Puijo. We noticed that there are two types of undefined days in Puijo. One is characterized by a burst in the number concentration of particles of the smallest detectable sizes but does not seem to show the characteristics of a NPF event day (i.e., growth to larger sizes; e.g., Fig. 3a) and most likely originate from local emissions. In the other type, some particles appear in larger sizes (with minor growth), which may or may not have originated from NPF processes (see e.g Fig. 3b). A clear NPF event with particle growth continuing several hours into the evening is shown in Fig. 3c.

The monthly number and yearly fraction of NPF event days recorded in Puijo from year 2007 to 2015 are shown in Figure 4. Note that size distribution data for 48 and $44 \%$ of the days are missing during years 2010 and 2012, respectively. Figure 4 shows that a maximum number of event days occurred during springtime, similar to NPF events reported in Hyytiälä (Dal Maso et al., 2005). There are 105 quantifiable NPF event days for which we calculated the $J_{3 \text {, est }}$ at Puijo. Figure 5 shows the seasonal mean values of $J_{3 \text {,est }}$ and $J_{7 \text {,obs }}, \mathrm{GR}_{7-20}$, and coagulation sink for $7 \mathrm{~nm}$ particles (CoagS $(d=7 \mathrm{~nm})$ ) for the quantifiable NPF event days in Puijo. The total mean of $J_{3 \text {, est }}$ is 0.61 , while the corresponding value for $J_{7, \mathrm{obs}}$ is $0.44 \mathrm{~cm}^{-3} \mathrm{~s}^{-1}$. Total means of $\mathrm{GR}_{7-20}$ and CoagS of $7 \mathrm{~nm}$ particles for NPF days are $5.8 \mathrm{~nm} \mathrm{~h}^{-1}$ and 
$1.84 \times 10^{-4} \mathrm{~s}^{-1}$, respectively. Thus, the mean GR at Puijo is somewhat higher compared to Hyytiälä, where a median value of $\mathrm{GR}=4.3 \mathrm{~nm} \mathrm{~h}^{-1}$ is reported for the period April 2003-December 2009 (Yli-Juuti et al., 2011). As the growth rates in Puijo are on average higher, there is less time needed for the particles to grow from 3 to $7 \mathrm{~nm}$. This means that our assumption of time-independent growth rate and coagulation sink during growth should hold in Puijo as well as in Hyytiälä.

Table 1 summarizes the seasonal means of parameters presented in Fig. 5. The seasonal mean $3 \mathrm{~nm}$ particle formation rates seem to have the highest values during summer $\left(1.12 \mathrm{~cm}^{-3} \mathrm{~s}^{-1}\right.$ for $17 \mathrm{NPF}$ days $)$ and spring $\left(0.70 \mathrm{~cm}^{-3} \mathrm{~s}^{-1}\right.$ for 68 NPF days) and drop significantly in fall and winter. The seasonal mean of the growth rate has its maximum in summer $\left(8.0 \mathrm{~nm} \mathrm{~h}^{-1}\right)$ and minimum in winter $\left(2.3 \mathrm{~nm} \mathrm{~h}^{-1}\right)$. The seasonal means of CoagS values for $7 \mathrm{~nm}$ during NPF event days are highest in summer and lowest in winter in Puijo.

\section{Conclusions}

In this study, the formation rates of $3 \mathrm{~nm}$ particles in SMEAR IV, Puijo (Finland), were estimated. The measurements at Puijo extend only down to $7 \mathrm{~nm}$ in diameter, which means that we had to extrapolate to $3 \mathrm{~nm}$ using aerosol dynamics theory. The approach used here is based on the competing processes of condensational growth and scavenging onto background aerosols, assuming time- and size-independent growth rate and time-independent coagulation sink in the range 3 to $7 \mathrm{~nm}$.

To first evaluate our extrapolation method, we applied it to particle formation events at Hyytiälä, where DMPS measurements extend down to $3 \mathrm{~nm}$, and formation rates at $3 \mathrm{~nm}$ $\left(J_{3, \text { obs }}\right)$ and $7 \mathrm{~nm}\left(J_{7, \text { obs }}\right)$ can thus be determined directly from the measured size distribution evolution. The results show that the estimated daily mean values of $J_{3}$ are in reasonably good agreement with observed mean $J_{3}$, with $91 \%$ of the estimated $J_{3}$ within a factor of 2 from the measured ones and mostly overestimated. However, when considering detailed daily time evolution, the agreement is not as good. This is caused by three main things. First, there are significant fluctuations in experimental size distribution data due to, for example, changes in the sampled air masses. This kind of fluctuations is not taken into account in Eq. (1). Second, the extrapolation method assumes a constant value for CoagS / GR. If this is not the case, it affects both the time evolution (determined by GR) and the magnitude of the estimated $J$ (determined by the ratio CoagS / GR). Third, there is a time lag between $J_{3}$ and $J_{7}$, and a poor estimation of the growth rate results in comparing values at different times. Estimating $\mathrm{GR}_{3-10}$, as was shown from Hyytiälä data, does not seem to give in all cases satisfactory results for this purpose. It should be noted that we have to estimate GR from the data above $7 \mathrm{~nm}$ for the Puijo site due to the lack of the measured data below $7 \mathrm{~nm}$.

At Puijo, the mean of $J_{7}$ for quantifiable particle formation days was $0.44 \mathrm{~cm}^{-3} \mathrm{~s}^{-1}$, while the extrapolated mean $J_{3}$ was $0.61 \mathrm{~cm}^{-3} \mathrm{~s}^{-1}$. These are about 2 times greater than the corresponding values in Hyytiälä. The ultimate aim of this work was to predict nucleation rates from size distribution measurements that do not extend to sizes lower than $7 \mathrm{~nm}$. The results obtained in this study suggest this is very challenging, in large part due to the difficulty in reliably predicting the growth rate down to around $1.5 \mathrm{~nm}$. It is noted that the possible size dependence of this growth rate further complicates the matter.

Data availability. The data sets from this study are available upon request from the corresponding author (kari.lehtinen@uef.fi). The aerosol number size distribution data from all the SMEAR stations are publicly available at https://avaa.tdata.fi/web/smart/smear (Junninen et al., 2009).

Competing interests. The authors declare that they have no conflict of interest.

Special issue statement. This article is part of the special issue "Pan-Eurasian Experiment (PEEX)". It is not associated with a conference.

Acknowledgements. We gratefully acknowledge the financial support by the Academy of Finland Center of Excellence program (project numbers 272041, 1118615, 307331), the Nordic Centre of Excellence CRAICC, University of Eastern Finland (UEF) strategic funding, and ACTRIS (under the European Union Seventh Framework Programme (FP7/2007-2013) grant agreement no. 262254 and Horizon 2020 research and innovation programme under grant agreement no. 654109), and Academy of Finland (project number 299544).

Edited by: Aijun Ding

Reviewed by: three anonymous referees

\section{References}

Aalto, P., Hämeri, K., Becker, E., Weber, R., Salm, J., Mäkelä, J., Hoell, C., O'dowd, C., Hansson, H.-C., Väkevä, M., Koponen, I., Buzorius, G., and Kulmala, M.: Physical characterization of aerosol particles during nucleation events, Tellus B, 53, 344-358, https://doi.org/10.3402/tellusb.v53i4.17127, 2001.

Almeida, J., Schobesberger, S., Kürten, A., Ortega, I. K., Kupiainen-Määttä, O., Praplan, A. P., Adamov, A., Amorim, A., Bianchi, F., Breitenlechner, M., David, A., Dommen, J., Donahue, N. M., Downard, A., Dunne, E., Duplissy, J., Ehrhart, S., Flagan, R. C., Franchin, A., Guida, R., Hakala, J., Hansel, A., 
Heinritzi, M., Henschel, H., Jokinen, T., Junninen, H., Kajos, M., Kangasluoma, J., Keskinen, H., Kupc, A., Kurtén, T., Kvashin, A. N., Laaksonen, A., Lehtipalo, K., Leiminger, M., Leppä, J., Loukonen, V., Makhmutov, V., Mathot, S., McGrath, M. J., Nieminen, T., Olenius, T., Onnela, A., Petäjä, T., Riccobono, F., Riipinen, I., Rissanen, M., Rondo, L., Ruuskanen, T., Santos, F. D., Sarnela, N., Schallhart, S., Schnitzhofer, R., Seinfeld, J. H., Simon, M., Sipilä, M., Stozhkov, Y., Stratmann, F., Tomé, A., Tröstl, J., Tsagkogeorgas, G., Vaattovaara, P., Viisanen, Y., Virtanen, A., Vrtala, A., Wagner, P. E., Weingartner, E., Wex, H., Williamson, C., Wimmer, D., Ye, P., Yli-Juuti, T., Carslaw, K. S., Kulmala, M., Curtius, J., Baltensperger, U., Worsnop, D. R., Vehkamäki, H., and Kirkby, J: Molecular understanding of sulphuric acid-amine particle nucleation in the atmosphere, Nature, 502, 359-363, https://doi.org/10.1038/nature12663, 2013.

Berndt, T., Sipilä, M., Stratmann, F., Petäjä, T., Vanhanen, J., Mikkilä, J., Patokoski, J., Taipale, R., Mauldin III, R. L., and Kulmala, M.: Enhancement of atmospheric $\mathrm{H}_{2} \mathrm{SO}_{4} / \mathrm{H}_{2} \mathrm{O}$ nucleation: organic oxidation products versus amines, Atmos. Chem. Phys., 14, 751-764, https://doi.org/10.5194/acp-14-751-2014, 2014.

Bianchi, F., Tröstl, J., Junninen, H., Frege, C., Henne, S., Hoyle, C. R., Molteni, U., Herrmann, E., Adamov, A., Bukowiecki, N., Chen, X., Duplissy, J., Gysel, M., Hutterli, M., Kangasluoma, J., Kontkanen, J., Kürten, A., Manninen, H. E., Münch, S., Peräkylä, O., Petäjä, T., Rondo, L., Williamson, C., Weingartner, E., Curtius, J., Worsnop, D. R., Kulmala, M., Dommen, J., and Baltensperger, U.: New particle formation in the free troposphere: A question of chemistry and timing, Science, 352, 1109-1112, https://doi.org/10.1126/science.aad5456, 2016.

Dal Maso, M., Kulmala, M., Riipinen, I., Wagner, R., Hussein, T., Aalto, P. P., and Lehtinen, K. E. J.: Formation and growth of fresh atmospheric aerosols: eight years of aerosol size distribution data from SMEAR II, Hyytiälä, Finland, Boreal Environ. Res., 10, 323-336, 2005.

Fuzzi, S., Baltensperger, U., Carslaw, K., Decesari, S., Denier van der Gon, H., Facchini, M. C., Fowler, D., Koren, I., Langford, B., Lohmann, U., Nemitz, E., Pandis, S., Riipinen, I., Rudich, Y., Schaap, M., Slowik, J. G., Spracklen, D. V., Vignati, E., Wild, M., Williams, M., and Gilardoni, S.: Particulate matter, air quality and climate: lessons learned and future needs, Atmos. Chem. Phys., 15, 8217-8299, https://doi.org/10.5194/acp15-8217-2015, 2015.

Iida, K., Stolzenburg, M. R., and McMurry, P. H.: Effect of Working Fluid on Sub-2 nm Particle Detection with a Laminar Flow Ultrafine Condensation Particle Counter, Aerosol Sci. Tech,, 43, 81-96, https://doi.org/10.1080/02786820802488194, 2009.

Jokinen, V. and Mäkelä, J. M.: Closed-loop arrangement with critical orifice for DMA sheath/excess flow system, J. Aerosol Sci., 28, 643-648, 1997.

Junninen, H., Lauri, A., Keronen, P., Aalto, P., Hiltunen, V., Hari, P., and Kulmala, M.: Smart-SMEAR: on-line data exploration and visualization tool for SMEAR stations, Boreal Environ. Res., 14, 447-457, 2009.

Kerminen, V.-M. and Kulmala, M.: Analytical formulae connecting the "real" and the "apparent" 25 nucleation rate and the nuclei number concentration for atmospheric nucleation events, J. Aerosol Sci., 33, 609-622, https://doi.org/10.1016/S00218502(01)00194-X, 2002.
Kerminen, V.-M., Lehtinen, K. E. J., Anttila, T., and Kulmala, M.: Dynamics of atmospheric nucleation mode particles: a timescale analysis, Tellus B, 56, 135-146, https://doi.org/10.1111/j.16000889.2004.00095.x, 2003.

Kerminen, V.-M., Anttila, T., Lehtinen, K. E. J., and Kulmala, M.: Parameterization for atmospheric new-particle formation: Application to a system involving sulfuric acid and condensable water-soluble organic vapors, Aerosol Sci. Tech., 38, 1001-1008, https://doi.org/10.1080/027868290519085, 2004.

Kerminen, V.-M., Paramonov, M., Anttila, T., Riipinen, I., Fountoukis, C., Korhonen, H., Asmi, E., Laakso, L., Lihavainen, H., Swietlicki, E., Svenningsson, B., Asmi, A., Pandis, S. N., Kulmala, M., and Petäjä, T.: Cloud condensation nuclei production associated with atmospheric nucleation: a synthesis based on existing literature and new results, Atmos. Chem. Phys., 12, 12037 12059, https://doi.org/10.5194/acp-12-12037-2012, 2012.

Kirkby, J., Duplissy, J., Sengupta, K., Frege, C., Gordon, H., Williamson, C., Heinritzi, M., Simon, M., Yan, C., Almeida, J., Tröstl, J., Nieminen, T., Ortega, I. K., Wagner, R., Adamov, A., Amorim, A., Bernhammer, A.-K., Bianchi, F., Breitenlechner, M., Brilke, S., Chen, X., Craven, J., Dias, A., Ehrhart, S., Flagan, R. C., Franchin, A., Fuchs, C., Guida, R., Hakala, J., Hoyle, C. R., Jokinen, T., Junninen, H., Kangasluoma, J., Kim, J., Krapf, M., Kürten, A., Laaksonen, A., Lehtipalo, K., Makhmutov, V., Mathot, S., Molteni, U., Onnela, A., Peräkylä, O., Piel, F., Petäjä, T., Praplan, A. P., Pringle, K., Rap, A., Richards, N. A. D., Riipinen, I., Rissanen, M. P., Rondo, L., Sarnela, N., Schobesberger, S., Scott, C. E., Seinfeld, J. H., Sipilä, M., Steiner, G., Stozhkov, Y., Stratmann, F., Tomé, A., Virtanen, A., Vogel, A. L., Wagner, A., Wagner, P. E., Weingartner, E., Wimmer, D., Winkler, P. M., Ye, P., Zhang, X., Hansel, A., Dommen, J., Donahue, N. M., Worsnop, D. R., Baltensperger, U., Kulmala, M., Carslaw, K. S., and Curtius, J.: Ion-induced nucleation of pure biogenic particles, Nature, 533, 521-526, https://doi.org/10.1038/nature17953, 2016.

Korhonen, H., Kerminen, V. M., Kokkola, H., and Lehtinen, K. E. J.: Estimating atmospheric nucleation rates from size distribution measurements: Analytical equations for the case of size dependent growth rates, J. Aerosol Sci., 69, 13-20, https://doi.org/10.1016/j.jaerosci.2013.11.006, 2014.

Korhonen, P., Kulmala, M., Laaksonen, A., Viisanen, Y., McGraw, R., and Seinfeld, J. H.: Ternary nucleation of $\mathrm{H}_{2} \mathrm{SO}_{4}, \mathrm{NH}_{3}$, and $\mathrm{H}_{2} \mathrm{O}$ in the atmosphere, J. Geophys. Res.-Atmos., 104, 2634926353, https://doi.org/10.1029/1999JD900784, 1999.

Kuang, C., Chen, M., McMurry, P. H., and Wang, J.: Modification of laminar flow ultrafine condensation particle counters for the enhanced detection of $1 \mathrm{~nm}$ condensation nuclei, Aerosol Sci. Tech., 46, 309-315, 2012.

Kulmala, M., Liisa, P., and Mäkelä, J. M.: Stable sulphate clusters as a source of new atmospheric particles, Nature, 404, 66-69, https://doi.org/10.1038/35003550, 2000.

Kulmala, M., Hämeri, K., Aalto, P. P., Mäkelä, J. M., Pirjola, L., Nilsson, E. D., Buzorius, G., Rannik, Ü., Maso, M. D., Seidl, W., Hoffman, T., Janson, R., Hansson, H.-C., Viisanen, Y., Laaksonen, A., and O'Dowd, C. D.: Overview of the international project on biogenic aerosol formation in the boreal forest (BIOFOR), Tellus B, 53, 324-343, 2001.

Kulmala, M., Vehkamäki, H., Petäjä, T., Dal Maso, M., Lauri, A., Kerminen, V.-M., Birmili, and W., McMurry, P. H.: 
Formation and growth rates of ultrafine atmospheric particles: a review of observations, J. Aerosol Sci., 35, 143-76, https://doi.org/10.1016/j.jaerosci.2003.10.003, 2004.

Kulmala, M., Lehtinen, K. E. J., and Laaksonen, A.: Cluster activation theory as an explanation of the linear dependence between formation rate of $3 \mathrm{~nm}$ particles and sulphuric acid concentration, Atmos. Chem. Phys., 6, 787-793, https://doi.org/10.5194/acp-6787-2006, 2006.

Kulmala, M., Petäjä, T., Nieminen, T., Sipilä, M., Manninen, H. E., Lehtipalo, K., Dal Maso, M., Aalto, P. P, Junninen, H., Paasonen, P., Riipinen, I., Lehtinen, K. E. J., Laaksonen, A., and Kerminen, V.-M.: Measurement of the nucleation of atmospheric aerosol particles, Nat. Protoc., 7, 1651-1667, https://doi.org/10.1038/nprot.2012.091, 2012.

Kulmala, M., Kontkanen, J., Junninen, H., Lehtipalo, K., Manninen, H. E., Nieminen, T., Petäjä, T., Sipilä, M., Schobesberger, S., Rantala, P., Franchin, A., Jokinen, T., Järvinen, E., Äijälä, M., Kangasluoma, J., Hakala, J., Aalto, P. P., Paasonen, P., Mikkilä, J., Vanhanen, J., Aalto, J., Hakola, H., Makkonen, U., Ruuskanen, T., Mauldin, R. L., Duplissy, J., Vehkamäki, H., Bäck, J., Kortelainen, A., Riipinen, I., Kurten, T., Johnston, M. V., Smith, J. N., Ehn, M., Mentel, T. F., Lehtinen, K. E. J., Laaksonen, A., Kerminen, V.-M., and Worsnop, D. R.: Direct Observations of Atmospheric Aerosol Nucleation, Science, 339, 943946, https://doi.org/10.1126/science.1227385, 2013.

Kürten, A., Williamson, C., Almeida, J., Kirkby, J., and Curtius, J.: On the derivation of particle nucleation rates from experimental formation rates, Atmos. Chem. Phys., 15, 4063-4075, https://doi.org/10.5194/acp-15-4063-2015, 2015.

Laakso, L., Petäjä, T., Lehtinen, K. E. J., Kulmala, M., Paatero, J., Hõrrak, U., Tammet, H., and Joutsensaari, J.: Ion production rate in a boreal forest based on ion, particle and radiation measurements, Atmos. Chem. Phys., 4, 1933-1943, https://doi.org/10.5194/acp-4-1933-2004, 2004.

Laaksonen, A., Kulmala, M., Berndt, T., Stratmann, F., Mikkonen, S., Ruuskanen, A., Lehtinen, K. E. J., Dal Maso, M., Aalto, P., Petäjä, T., Riipinen, I., Sihto, S.-L., Janson, R., Arnold, F., Hanke, M., Ücker, J., Umann, B., Sellegri, K., O’Dowd, C. D., and Viisanen, Y.: $\mathrm{SO}_{2}$ oxidation products other than $\mathrm{H}_{2} \mathrm{SO}_{4}$ as a trigger of new particle formation. Part 2: Comparison of ambient and laboratory measurements, and atmospheric implications, Atmos. Chem. Phys., 8, 7255-7264, https://doi.org/10.5194/acp8-7255-2008, 2008.

Lehtinen, K. E. J. and Kulmala, M.: A model for particle formation and growth in the atmosphere with molecular resolution in size, Atmos. Chem. Phys., 3, 251-257, https://doi.org/10.5194/acp-3251-2003, 2003.

Lehtinen, K. E. J., Korhonen, H., Dal Maso, M., and Kulmala, M.: On the concept of condensation sink diameter, Boreal Environ. Res., 8, 405-411, 2003.

Lehtinen, K. E. J., dal Maso, M., Kulmala, M., and Kerminen, V.M.: Estimating nucleation rates from apparent particle formation rates and vice versa: Revised formulation of the KerminenKulmala equation, J. Aerosol Sci., 38, 988-994, 2007.

Leskinen, A., Portin, H., Komppula, M., Miettinen, P., Arola, A., Lihavainen, H., Hatakka, J., Laaksonen, A., and Lehtinen, K. E. J.: Overview of the research activities and results at Puijo semiurban measurement station, Boreal Environ. Res., 14, 576-590, 2009.
McMurry, P. H.: New particle formation in the presence of an aerosol: Rates, time scales and sub- $0.01 \mathrm{~mm}$ size distributions, J. Colloid Interf. Sci., 95, 72-80, 1983.

McMurry, P. H. and Friedlander, S. K.: New particle formation in the presence of an aerosol, Atmos. Environ., 13, 1635-1651, 1979.

McMurry, P. H. and Wilson, J. C.: Growth laws for the formation of secondary ambient aerosols: Implications for chemical conversion mechanisms, Atmos. Environ., 16, 121-134, https://doi.org/10.1016/0004-6981(82)90319-5, 1982.

Merikanto, J., Spracklen, D. V., Mann, G. W., Pickering, S. J., and Carslaw, K. S.: Impact of nucleation on global CCN, Atmos. Chem. Phys., 9, 8601-8616, https://doi.org/10.5194/acp-9-86012009, 2009.

Minguillón, M. C., Brines, M., Pérez, N., Reche, C., Pandolfi, M., Fonseca, A. S., Amato, F., Alastuey, A., Lyasota, A., Codina, B., Lee, H.-K., Eun, H.-R., Ahn, K.-H., and Querol, X.: New particle formation at ground level and in the vertical column over the Barcelona area, Atmos. Res., 164-165, 118-130, https://doi.org/10.1016/j.atmosres.2015.05.003, 2015.

Nie, W., Ding, A., Wang, T., Kerminen, V.-M., George, C., Xue, L., Wang, W., Zhang, Q., Petäjä, T., Qi, X., Gao, X., Wang, X., Yang, X., Fu, C., and Kulmala, M.: Polluted dust promotes new particle formation and growth, Scientific Reports, 4, 6634, https://doi.org/10.1038/srep06634, 2014.

Portin, H., Leskinen, A., Hao, L., Kortelainen, A., Miettinen, P., Jaatinen, A., Laaksonen, A., Lehtinen, K. E. J., Romakkaniemi, S., and Komppula, M.: The effect of local sources on particle size and chemical composition and their role in aerosol-cloud interactions at Puijo measurement station, Atmos. Chem. Phys., 14, 6021-6034, https://doi.org/10.5194/acp-14-6021-2014, 2014.

Sgro, L. A. and Fernández de la Mora, J.: A Simple Turbulent Mixing $\mathrm{CNC}$ for Charged Particle Detection Down to $1.2 \mathrm{~nm}$, Aerosol Sci. Tech., 38, 1-11, https://doi.org/10.1080/02786820490247560, 2004.

Vanhanen, J., Mikkilä, J., Lehtipalo, K., Sipilä, M., Manninen, H. E., Siivola, E., Petäjä, T., and Kulmala, M.: Particle Size Magnifier for Nano-CN Detection, Aerosol Sci. Tech., 45, 533-542, 2011.

Vuollekoski, H., Sihto, S.-L., Kerminen, V.-M., Kulmala, M., and Lehtinen, K. E. J.: A numerical comparison of different methods for determining the particle formation rate, Atmos. Chem. Phys., 12, 2289-2295, https://doi.org/10.5194/acp12-2289-2012, 2012.

Weber, R. J., McMurry, P. H., Eisele, F. L., and Tanner, D. J.: Measurement of Expected Nucleation Precursor Species and 3-500nm Diameter Particles at Mauna Loa Observatory, Hawaii, J. Atmos. Sci., 52, 2242-2257, 1995.

Weber, R. J., Marti, J. J., and McMurry, P. H., Eisele, F. L., Tanner, D. J., and Jefferson, A.: Measured atmospheric new particle formation rates: implications for nucleation mechanisms, Chem. Eng. Commun., 151, 53-64, https://doi.org/10.1080/00986449608936541, 1996.

Wimmer, D., Lehtipalo, K., Franchin, A., Kangasluoma, J., Kreissl, F., Kürten, A., Kupc, A., Metzger, A., Mikkilä, J., Petäjä, T., Riccobono, F., Vanhanen, J., Kulmala, M., and Curtius, J.: Performance of diethylene glycol-based particle counters in the sub-3 nm size range, Atmos. Meas. Tech., 6, 1793-1804, https://doi.org/10.5194/amt-6-1793-2013, 2013. 
Winklmayr, W., Reischl, G. P., Linder, A. O., and Berner, A.: A new electromobility spectrometer for the measurement of aerosol size distribution in the size range 1 to $1000 \mathrm{~nm}$, J. Aerosol Sci., 22, 289-296, 1991.

Xiao, S., Wang, M. Y., Yao, L., Kulmala, M., Zhou, B., Yang, X., Chen, J. M., Wang, D. F., Fu, Q. Y., Worsnop, D. R., and Wang, L.: Strong atmospheric new particle formation in winter in urban Shanghai, China, Atmos. Chem. Phys., 15, 1769-1781, https://doi.org/10.5194/acp-15-1769-2015, 2015.

Yli-Juuti, T., Nieminen, T., Hirsikko, A., Aalto, P. P., Asmi, E., Hõrrak, U., Manninen, H. E., Patokoski, J., Dal Maso, M., Petäjä, T., Rinne, J., Kulmala, M., and Riipinen, I.: Growth rates of nucleation mode particles in Hyytiälä during 20032009: variation with particle size, season, data analysis method and ambient conditions, Atmos. Chem. Phys., 11, 12865-12886, https://doi.org/10.5194/acp-11-12865-2011, 2011.
Zhou, J.: Hygroscopic Properties of Atmospheric Aerosol Particles in Various Environments, PhD thesis, University of Lund, Division of Nuclear Physics, Sweden, http://lup.lub.lu.se/record/ 41435 (last access: 10 October 2017), 2001. 